\title{
Effect of Tillage and Cultural Practices on Growth, Yield and Economics of Kodo Millet
}

\author{
Kumer Singh Malviya ${ }^{1 *}$, L. Bakoriya ${ }^{2}$, S. Kumar ${ }^{1}$, S. Aske ${ }^{1}$, \\ G. Mahajan ${ }^{1}$ and K.D. Malviya ${ }^{3}$ \\ ${ }^{1}$ Department of Agronomy, JNKVV College of Agriculture, Rewa-486 001 (M.P.), India \\ ${ }^{2}$ Department of Agronomy, JNKVV College of Agriculture, Tikamgarh 472001(M.P.), India \\ ${ }^{3}$ Department of Agronomy, M.G. Chitrakoot Ramodaya Vishwavidyalaya Chitrakoot, \\ Satna-485780 (M.P.), India \\ *Corresponding author
}

\begin{abstract}
A B S T R A C T

\begin{tabular}{|l|}
\hline Ke y w or d s \\
$\begin{array}{l}\text { Tillage, Cultural } \\
\text { practices, Kodo } \\
\text { millet }\end{array}$ \\
\hline Article Info \\
\hline $\begin{array}{l}\text { Accepted: } \\
\text { 10 May } 2019 \\
\text { Available Online: } \\
\text { 10 June 2019 }\end{array}$ \\
\hline
\end{tabular}

A field experiment was carried out during rainy season of 2016 at the Instructional Farm, JNKVV College of Agriculture, Rewa (M.P.) "To study the effect of tillage and cultural practices on growth, yield and economics of kodo millet". Kodo millet crop when grown by adopting conservation tillage practices and sowing of pigeonpea as intercrop followed by opening of conservation furrow between paired rows of pigeonpea $\left(\mathrm{C}_{2}\right)$ resulted in better growth and development of kodo millet over rest of the tillage and cultural practices. Conservation tillage $\left(T_{2}\right)$ was found the most suitable tillage practice for growing kodo millet crop under skeletal soil. The net return as well as benefit: cost ratio was reckoned highest from the treatment $\left(\mathrm{T}_{2} \mathrm{C}_{2}\right)$ here intercropping of kodo millet + pigeonpea was done followed by opening in the ratio of 2:4 conservation furrows between paired rows of pigeonpea due to the higher price of pigeonpea over the kodo millet. Whereas, the farmers obtaining for sole kodo millet should grow kodo millet by adopting conservation tillage and application of crop residue as mulch for obtaining higher benefit.
\end{abstract}

\section{Introduction}

Kodo millet is grown on marginal lands with poor management practices; therefore, intercropping with pigeonpea is recommended (Anonymous, 2008). It is getting more attention today due to increasing incidence of less seasonal rainfall, terminal heat, frequent occurrence of extreme weather event coupled with scanty water resources
(Singh et al., 2010). When these crops are intercropped with pigeonpea are benefitted to be advantages as these crops are able to use the growth resources differently and make better use of growth resources than grown in sole cropping. Pigeonpea is a late maturing, tall growing, wide spaced crop with deep root system and can be accommodated with rapidly growing, short duration and statured crops like kodo millets. 
The conservation tillage system impact soil moisture status because it influences infiltration, runoff, evaporation and soil water storage. Conservation tillage system is a method in which at least $30 \%$ of soil surface remains covered by crop residues. Conservation tillage as compared to conventional tillage improves soil and water resources, save energy and time, and reduces the cost of Agricultural production. As compared to conventional tillage, minimum tillage protects the soil from wind and water erosion, favours microbial growth; improved soil structure, increased infiltration rate, soil respiration, dehydrogenase activity in upper layer, soil organic carbon and soil microbial biomass is significantly congenial in minimum tillage as compared to conventional tillage (Singh et al., 2007). Research work on improved tillage practices coupled with intercropping of kodo millet with pigeonpea has not been done in Rewa region of Madhya Pradesh. Therefore, the present research was taken up.

\section{Materials and Methods}

The field experiment was carried out during the rainy season 2016 at the Instructional Farm, JNKVV College of Agriculture, Rewa (M.P.). The soil of the experimental field was sandy having $\mathrm{pH} 7.7$, electrical conductivity $0.5 \mathrm{dS} / \mathrm{m}$, organic carbon $0.53 \%$, available $\mathrm{N}$, $\mathrm{P}_{2} \mathrm{O}_{5}$ and $\mathrm{K}_{2} \mathrm{O} 225,12.52$ and $443 \mathrm{~kg} / \mathrm{ha}$, respectively. The treatments were 2 tillage practices in main plots and 6 cultural practices in the sub-plots.

\begin{tabular}{|l|l|}
\hline $\mathbf{T}_{1}$ & $\begin{array}{l}\text { Conventional tillage: } \mathbf{4} \text { ploughing }+ \text { secondary tillage for seed bed preparation } \\
\text { (farmers practice) }\end{array}$ \\
\hline $\mathbf{T}_{\mathbf{2}}$ & Conservation tillage/minimum tillage: 2 ploughings + secondary tillage. \\
\hline $\mathbf{C}_{\mathbf{1}}$ & Opening conservation furrow after every 6 rows. \\
\hline $\mathbf{C}_{2}$ & $\begin{array}{l}\text { Intercropping of kodo millet }+ \text { red gram and opening conservation furrows between } \\
\text { paired rows of pigeonpea. }\end{array}$ \\
\hline $\mathbf{C}_{3}$ & Mulching with crop residues. \\
\hline $\mathbf{C}_{4}$ & Weedicide application (pre emergent: Isoproturon @ 0.5kg a.i./ha). \\
\hline $\mathbf{C}_{\mathbf{5}}$ & Sole kodo millet crop. \\
\hline $\mathbf{C}_{6}$ & $\mathrm{C}_{1}+\mathrm{C}_{3}+\mathrm{C}_{4}+\mathrm{C}_{5}$. \\
\hline
\end{tabular}

An uniform basal dose of $20 \mathrm{~kg}$ nitrogen and $20 \mathrm{~kg}$ phosphorus/ha was applied through urea and DAP and $20 \mathrm{~kg}$ nitrogen/ha was applied as top dressing through urea in all treatments.

The kodo millet variety "RK $390-25$ " was sown on $20^{\text {th }}$ July 2016 @ $11 \mathrm{~kg}$ seed/ha and pigeonpea variety ICPH-87119 was sown on $20^{\text {th }}$ July 2016 keeping row to row spacing 30 $\mathrm{cm}$ and $60 \mathrm{~cm}$, and plant to plant $10 \mathrm{~cm}$ and $45 \mathrm{~cm}$ in kodo millet and pigeonpea, respectively. The kodo millet was harvested on 23rd September 2016 and pigeonpea was harvested on 28th February, 2017. The total rains received from June 2016 to February, 2017 were $1502 \mathrm{~mm}$.

\section{Results and Discussion}

\section{Growth parameters}

The chief characters of number of leaves/plant, and dry matter accumulation govern the growing habits of a crop. Both tillage and the cultural practices had a significant effect upon growth characters. Kodo millet crop sown by adopting 
conservation tillage practices gave better expression of growth characters. Viz., number of leaves/plant, and dry matter production. It might be due to the fact that conventional tillage practices resulted in losses of soil water and nutrient in field and degraded the soil to low organic matter content and a fragile physical structure, which in turn led to low crop yields. Similar finding has been reported by Wang et al., (2007) and Lal, (2002) Intercropping of kodo mill et al., ong with red gram and opening of conservation furrow resulted in highest mean number of leaves per plant. Enhanced number of leaves/plant contributed to increased plant fresh weight and finally to the dry matter production reported the similar finding and postulated that under cooler soil condition plant can grow vigorously contributing to increased plant biomass. Salhin et al., 2013, Palaniappan and Sivaraman, (1994) and Subbareddy and Venkateshwarlu, (1992) were of same opinion.

\section{Yield attributing characters}

The final outcome of crop is yield which is directly governed by various yield attributing characters. As per the present finding the yield attributing characters viz., number of panicle/meter row length, length of panicle $(\mathrm{cm})$, number of grains/panicle, weight of grains/panicle and test weight (g) were significantly influenced by the tillage and cultural practices. The above stated yield attributes were found maximum under conservational tillage practices. Sowing of kodo millet under intercropping system along with opening of conservation furrow proved superior and resulted in higher value for all the yield attributing characters. The most possible explanation for better yield attributes under these cultural practices may be that the beneficial effect of nitrogen fixation by legume supported the better expression of yield attributes. The variation in yield attributing characters in kodo millet and other small millets have also been reported by many research workers (Singh and Arya, 1994; Anonymous, 2000-2001; Patil et al., 2010).

\section{Grain and straw yield}

The results from the present experiment clearly indicate that tillage and the cultural practices had a significant effect on grain and straw yield the highest grain yield to the tune of $15.16 \mathrm{q} / \mathrm{ha}$ was obtained under conservation tillage which was $5.06 \%$ higher over the conventional tillage practices. Among cultural practices intercropping of kodo millet + pigeonpea in 4:2 row proportion and opening conservation furrows between paired rows of pigeonpea $\left(\mathrm{C}_{2}\right)$ resulted in highest grain yield of $17.51 \mathrm{q} / \mathrm{ha}$ which was $54.86 \%$ higher over the lowest yielding treatment $\mathrm{C}_{5}$. This might be due to the fact that mulching resulted in conservation of soil moisture and also prevented the loss of nutrient from soil and resulted in better expression of yield attributes and yield. This finding supports the work of Yadav et al., 2007. Thus, it is possible to assess the productivity of any cropping system with the productivity of only an individual crop component. Therefore combined yields of all components grown under a particular cropping sequence was determined as kodo millet equivalent yield on the basis of prevailing market price of the produce for an individual crop component under a particular cropping system play an important role on the kodo millet equivalent yield.

The kodo millet equivalent yield has been given in Table 1 reveals that kodo millet + red gram gave $22.01 \mathrm{q} /$ ha kodo millet grain equivalent yield which was significantly superior over all the cultural practices. This finding support the work of Singh et al., (2009), Kumar et al., (2009), Patil et al., (2010). 
Table.1 Growth, yield-attributes, yield and economics of kodo millet as influenced by tillage and cultural practices

\begin{tabular}{|c|c|c|c|c|c|c|c|c|c|c|c|c|c|c|}
\hline Treatments & $\begin{array}{c}\text { Plant } \\
\text { height } \\
\text { (cm) }\end{array}$ & $\begin{array}{l}\text { Tillers } \\
\text { /m row } \\
\text { length }\end{array}$ & $\begin{array}{c}\text { Leaves/ } \\
\text { plant }\end{array}$ & $\begin{array}{c}\text { Dry } \\
\text { matter/ } \\
\text { plant (g) }\end{array}$ & $\begin{array}{c}\text { Panicles } \\
\text { /m row } \\
\text { length }\end{array}$ & $\begin{array}{c}\text { Panicle } \\
\text { length } \\
\text { (cm) }\end{array}$ & $\begin{array}{l}\text { Grains/ } \\
\text { panicle }\end{array}$ & $\begin{array}{c}\text { Grains } \\
\text { weight/ } \\
\text { panicle } \\
\text { (g) }\end{array}$ & $\begin{array}{c}\text { Test } \\
\text { weight } \\
\text { (g) }\end{array}$ & $\begin{array}{c}\text { Grain } \\
\text { yield } \\
\text { (q/ha) }\end{array}$ & $\begin{array}{c}\text { Straw } \\
\text { yield } \\
\text { (q/ha) }\end{array}$ & $\begin{array}{c}\text { Harvest } \\
\text { index } \\
(\%)\end{array}$ & $\begin{array}{c}\text { Net } \\
\text { income } \\
\text { (Rs/ha) }\end{array}$ & $\begin{array}{l}\mathrm{B}: \mathrm{C} \\
\text { ratio }\end{array}$ \\
\hline \multicolumn{15}{|l|}{ Tillage practices } \\
\hline $\mathbf{T}_{1}$ & 65.66 & 83.58 & 19.79 & 1.82 & 81.57 & 26.8 & 147 & 1.22 & 4.05 & 14.43 & 43.66 & 24.81 & 21516 & 1.76 \\
\hline $\mathbf{T}_{2}$ & 67.46 & 87.11 & 20.79 & 1.93 & 86.05 & 27.3 & 155 & 1.26 & 4.12 & 15.16 & 45.04 & 25.30 & 25061 & 1.91 \\
\hline C.D. $(P=0.05)$ & NS & NS & NS & NS & NS & NS & NS & NS & NS & NS & 0.22 & NS & -- & -- \\
\hline \multicolumn{15}{|l|}{ Dates of sowing } \\
\hline $\mathrm{C}_{1}$ & 63.44 & 68.33 & 19.67 & 1.57 & 80.90 & 25.7 & 146 & 1.21 & 4.01 & 14.00 & 42.53 & 24.87 & 18634 & 1.68 \\
\hline $\mathbf{C}_{2}$ & 71.33 & 98.59 & 23.37 & 2.48 & 96.88 & 29.4 & 174 & 1.37 & 4.21 & 17.51 & 53.17 & 24.78 & 42967 & 2.52 \\
\hline $\mathbf{C}_{3}$ & 70.83 & 91.66 & 21.50 & 2.32 & 88.60 & 27.8 & 159 & 1.29 & 4.12 & 15.83 & 47.67 & 24.96 & 24853 & 1.91 \\
\hline $\mathrm{C}_{4}$ & 65.83 & 88.09 & 21.26 & 1.78 & 87.59 & 28.0 & 158 & 1.28 & 4.08 & 15.18 & 44.00 & 25.65 & 22429 & 1.89 \\
\hline $\mathrm{C}_{5}$ & 63.49 & 64.68 & 15.30 & 1.28 & 63.63 & 24.2 & 115 & 1.04 & 3.98 & 11.32 & 37.05 & 23.64 & 10900 & 1.41 \\
\hline $\mathrm{C}_{6}$ & 65.44 & 85.73 & 20.65 & 1.83 & 85.26 & 27.2 & 153 & 1.25 & 4.08 & 14.94 & 41.67 & 26.41 & 19948 & 1.69 \\
\hline C.D. $(\mathbf{P}=0.05)$ & 7.45 & 15.17 & 1.10 & 0.35 & 4.74 & 1.69 & 8.4 & 0.05 & NS & 0.83 & 2.94 & NS & -- & -- \\
\hline Interaction & NS & NS & NS & NS & NS & NS & NS & NS & NS & NS & Sig. & NS & -- & -- \\
\hline
\end{tabular}


Likewise straw yield was also found to be higher under conservation tillage practices. Whereas, among the cultural practices mulching with crop residues $\left(\mathrm{C}_{3}\right)$ resulting higher straw and opening conservation furrow after every $6^{\text {th }}$ rows along with $\mathrm{C}_{1}+\mathrm{C}_{4}+\mathrm{C}_{5}$ $\left(\mathrm{C}_{6}\right)$ resulted in lower straw yield while the maximum straw yield was recorded under intercropping system with opening of farrows $\left(\mathrm{C}_{2}\right)$.

\section{Economics}

The final outcome of crop production is represented in terms of monetary returns being obtained from the crop. Economics of the different treatment is directly related to the success of that particular treatment and the extra input and output due to that treatment. The highest net income was Rs.42967/ha in case of $\left(\mathrm{C}_{2}\right)$ intercropping of kodo millet + red gram and opening conservation furrows between paired rows of pigeonpea and the lowest net income was Rs.10900/ha in case of $\mathrm{C}_{5}$. The calculation of benefit: cost ratio is another way of expressing the economics of the treatments. It is based on the income as against the total expenditure incurred on that particular treatment. In the present study, the $\mathrm{B}: \mathrm{C}$ ratio of each treatment was obtained exactly in accordance with the net income received from that treatment. Accordingly treatment $\mathrm{C}_{2}$ registered the highest $\mathrm{B}: \mathrm{C}$ ratio upto 2.52 and the lowest $\mathrm{B}: \mathrm{C}$ ratio (1.41) was obtained in case of $\mathrm{C}_{5}$ treatment. The $\mathrm{C}_{3}$ treatment stood the second best in the economical grain because of lowest input cost, check weed growth and conserve soil moisture etc.

\section{References}

Anonymous. 2000-01. Response of prerelease varieties of kodo millet to levels of $\mathrm{N}$ under rainfed conditions. Annual Report. All India Co-ordinated Small
Millet Improvement Project, College of Agriculture, Rewa (M.P.).

Anonymous. 2008. Annual Progress Report. All India Coordinated Research Project for Small Millet. J.N.K.V.V. College of Agriculture. Rewa (M.P.).

Kumar, B.H.P., Halikatti, S.I. and Ninganur, B.T. 2009. Sustainable intercrop association of pigeonpea (Cajanus cajan) in little millet (Panicum sumatrence L.). Karn. J. Agri. Sci., 22(4): 887-888.

Lal, R. 2002. Soil carbon sequestration in China through agricultural intensification and restoration of degraded and decertified eco-systems. Land Degradation and Development, 13: 469-478.

Palaniappan, S.P. and Sivaraman, K. 1994. In: cropping systems in the tropics in principles and management, $2^{\text {nd }} \mathrm{Ed}$. New age International Pvt. Ltd., Publishers, New Delhi.

Patil, N.B., Halikatti, S.I., Sajay, Y.H., Kumar, P.B.H., Topagi, S.C. and Pushpa, V. 2010. Influence of intercropping on the growth and yield of little millet and pigeonpea. Int. J. Agri. Sci., 6 (2):573-577.

Salhin, N., Alam, M.K., Islam, M.M., Naher, L. and Majid, N.M. 2013. Effect of green manure crops and tillage practice on maize and rice yields and soil properties. Australian Journal of Crop Science, 7 (12): 1901-1911.

Singh, R.V., and Arya, M.P.S. 1994. Response of finger millet (Elcusine coracana) varieties to nitrogen under rainfed condition. Indian J. Agron. 39 (1): 125-128.

Singh, U.K., Bharti, N. and Kumar, V. 2009. System productivity and profitability of pigeonpea based intercropping under rainfed condition. J. Appl. Boil., 19 (12): 23-26. 
Subbreddy, G. and Venkateshwarlu, S. 1992. Effect of planting pattern on yield and moisture use efficiency in sunflowerpigeonpea intercropping system. Ind. $J$. Agron., 37(4): 659-665.

Wang, X.B., Cai, D.X., Peradok, U.D., Hoogmoed, W.B. and Ocnema, O. 2007. Development in conservation tillage in rainfed regions of North China. Soil Till. Res. 93: 239-250. Yadav, D.R., Dahal, K.R., Basnet, K.B., Chaudhary, N.K. and Duxbury, J.M. 2007. Effect of tillage on weed growth and yield of wheat in relation to time of nitrogen application and mulch. Ins. Agri. Ani. Sci. (IAAS) Res. Adv., 1:3136.

\section{How to cite this article:}

Kumer Singh Malviya, L. Bakoriya, S. Kumar, S. Aske, G. Mahajan and Malviya, K.D. 2019. Effect of Tillage and Cultural Practices on Growth, Yield and Economics of Kodo Millet. Int.J.Curr.Microbiol.App.Sci. 8(06): 890-895. doi: https://doi.org/10.20546/ijcmas.2019.806.107 